\title{
New Approach of Metal Substrate Fabrication for Metal-Supported Solid Oxide Fuel Cells
}

\author{
Anne Günther (Fraunhofer IKTS, Winterbergstraße 28, 01277 Dresden) \\ Tassilo Moritz (Fraunhofer IKTS, Winterbergstraße 28, 01277 Dresden) \\ Axel-Müller-Köhn (Fraunhofer IKTS, Winterbergstraße 28, 01277 Dresden) \\ Anja Härtel (Fraunhofer IKTS, Winterbergstraße 28, 01277 Dresden) \\ Mihails Kusnezoff (Fraunhofer IKTS, Winterbergstraße 28, 01277 Dresden) \\ Marco Fritsch (Fraunhofer IKTS, Winterbergstraße 28, 01277 Dresden) \\ Nikolai Trofimenko (Fraunhofer IKTS, Winterbergstraße 28, 01277 Dresden) \\ Irina Bremerstein (UVR-FIA GmbH, Chemnitzer Str. 40, 09599 Freiberg \\ Andre Kamptner (UVR-FIA GmbH, Chemnitzer Str. 40, 09599 Freiberg)
}

\begin{abstract}
Metal-supported fuel cells (MSCs) offer potential material cost and robustness advantage over anode supported cells (ASCs). Because of the very good thermal shock stability of such MSCs, these can be heated up very quickly. However the challenge co-firing of metal substrate and electrolyte stays still unsolved. The production of the core component, the tape casted metal substrate, with defined shrinkage resulting from modification of metal powders is presented in the paper. This approach leads to an adjustment of the shrinkage mismatch during sintering, between metal and ceramic components, and adjustment of target specifications like porosity, green density and layer thickness.
\end{abstract}

\section{Keywords}

Additive Manufacturing, 3D printing

\section{Introduction}

Increasing efficiency in energy systems and providing sufficient electrical energy is one of the key challenges for the future due to the growing world population and limited fossil energy sources [1]. A major contribution can be made by developing more efficient energy converters. Here, the fuel cell is of particular importance, since due to the direct conversion of chemical into electrical energy the highest efficiencies can be achieved [2].

Specifically, the solid oxide fuel cell (SOFC - solid oxide fuel cell) is characterized by a high fuel flexibility due to its resistance to impurities in the fuel gas [3]. In addition to hydrogen, carbon monoxide and, in the case of direct reforming, also hydrocarbon-containing gases can be used as a fuel in the SOFC due to the temperatures of 600 to $900{ }^{\circ} \mathrm{C}$ [4]. Furthermore, when using an upstream reformer, a variety of today's common fossil fuels (natural gas, diesel, etc.) and biogenic fuels like biogas can be used in the SOFC [5]. Currently, different SOFC systems in the power range of a few watts [6, 7] up to $0,5 \mathrm{MW}[8]$ are in field test and under commercialization worldwide [9]. The current focus of the further development of such systems is the increase in performance or efficiency and a reduction in manufacturing costs. A crucial aspect of this is the further development of the electrochemical cell, meaning the galvanic element of cathode, electrolyte and anode, hereinafter also referred as MEA unit (MEA - Membrane Electrode Assembly). In the context of developments in the field of SOFCs, different concepts and designs of the MEA unit have emerged through different companies. A meaningful subdivision of the currently existing solid oxide fuel cells can be made because of the geometric structure of the electrochemical cell and the resulting interconnection. One differentiates primarily into tubular and planar cells [10]. The mechanical strength of the ceramic support structures of ESC (Electrolyte Supported Cells), ASC (Anode Supported Cells) and CSC (Cathode Supported Cells) is problematic. In contrast, metallic materials do not exhibit the brittle fracture behavior typical of ceramic materials, which is why higher mechanical strengths can be achieved in the metal-supported cell. In addition, the price of ceramic support structures can be estimated by a factor of three to five compared to metallic support structures [12].

The metal-supported cell is often regarded in the literature as the newest cell generation for SOFCs [1315]. The reason that an intensive development of the metal-supported cell has taken place only in the past years of the last decade can be attributed to the requirement of a suitable metallic material for the support structure. Only through the development of new stack designs for the SOFC, based on metallic interconnector plates, at the beginning of the 90s [16], was a continuous development of suitable metallic materials necessary in the following years [17-22], which is the requirement for a successful 
implementation of the represent metal-supported cell. At the end of the nineties, the concept of the metal-supported cell in work at the German Aerospace Center (DLR) was taken up again [23] and in the following years in cooperation with well-known industrial partners (BMW / Munich, Elring-Klinger / Dettingen, Rhodius / Weissenburg) [24] developed further. In the course of developments at DLR, various metallic materials as supporting structures were investigated and used [13]. Currently, ferritic iron-chromium alloys are increasingly described in the literature for the material of the metallic support structure [11, 25, 26]. Due to the inherent interdiffusion of $\mathrm{Cr}, \mathrm{Fe}$ and $\mathrm{Ni}$ between the anode layer and the substrate, the chromium-rich alloys require an additional diffusion barrier layer in order to avoid disadvantageous changes in the anode and the substrate [27, 28].

\section{Experimental}

Stainless steel powder (Fe26Cr1MoTi, see Table 1) were used for the metal substrates. To influence the porosity and shrinkage properties of the substrates, the spherical starting powders were separated in two fractions with $-38 \mu \mathrm{m}$ and $-125+38 \mu \mathrm{m}$ and were milled by attritor ( $800 \mathrm{rpm}, 1-4 \mathrm{~h})$ or high energy milling (HEM, $1200 \mathrm{rpm}, 2-4 \mathrm{~h}$ ). The development of the composite was carried out by a powder technology process, the tape casting, which is known from ceramic shaping processes. Suspensions were prepared by powder homogenization in slurries with solvent mixture consisting of an azeotrope from ethanol and MEK (methyl ethyl ketone), organic binder (polyvinyl butyral from Kuraray) and plasticizing agent (polyethylene glycol from Carl Roth $\mathrm{GmbH}$ ). Finally the slurry is casted into green tapes. To achieve a consistent pore distribution, 1,4 wt.- $\%$ - relative to the powder quantity - of a pore former (Sekisui Co. Ltd.) was added to the suspensions. The entire content of additives depends on the form of the powder particles, respectively the amount of powder surface. Furthermore, the additive composition should be compatible with the corresponding zirconia tape, which can be laminated to the metal substrate prior to sintering. The suspensions were casted by applying the metal suspension onto a carrier tape using the doctor blade method. Metal substrates with dimensions of $70 \times 70 \mathrm{~mm}$ in green state are produced with constant green densities of $4.43 \mathrm{~g} / \mathrm{cm}^{3}$.

Next step was the thermal debinding to remove the organic additives from the metal substrate. This was performed in hydrogen atmosphere up to a temperature of $600^{\circ} \mathrm{C}$. The heating rate was $0,2 \mathrm{~K} / \mathrm{min}$ and the holding time $90 \mathrm{~min}$ with an intermediate holding at $400^{\circ} \mathrm{C}$ and $60 \mathrm{~min}$. During the subsequent sintering with a maximum temperature of $1350^{\circ} \mathrm{C}$ a heating rate of $0,5 \mathrm{~K} / \mathrm{min}$, a holding time at the maximum temperature for 3 hours and the sintering atmosphere consisted of 20 vol.- $\%$ hydrogen and 80 vol.- \% argon were set. Porous alumina plates with $100 \times 100 \mathrm{~mm}$ were used as kiln furniture and also to cover the substrates.

Table 1: Composition and amounts of elements for Fe26Cr1MoTi detected by XRF

\begin{tabular}{|c|c|c|c|c|c|}
\hline elements & $\mathrm{Fe}$ & $\mathrm{Cr}$ & $\mathrm{Mo}$ & $\mathrm{Ti}$ & residue \\
\hline amount $/$ wt.\% & 72,28 & 26,13 & 1,16 & 0,32 & 0,11 \\
\hline
\end{tabular}

For the determination of carbon and oxygen content hot gas extraction (Leco, CS666) was used. The density and open porosity of the sintered substrates was measured by Archimedean principle. For shrinkage and thickness of the substrates, the geometric dimensions were measured in green stage and after sintering. The pore size could be determined by microscopy. A field emission scanning electron micrograph (FESEM, Carl Zeiss, Gemini 982) was used for the investigation of the powder structures and sintered substrates. This characterization was primarily made on cross sections of the substrates. Table 1 shows the results of XRF analysis for the Fe26Cr1MoTi powder.

\section{Results and Discussion}

Both powder fractions of the Fe26Cr1MoTi were used for milling and tape casting to generate metal substrates for MSC. For this, the produced metal substrate tapes were characterized after sintering and compared with the requirements of an MSC substrate and as a consequence thereof for future co-firing with the $\mathrm{ZrO}_{2}$ electrolyte layer. For the substrates an open porosity of 35-50 vol.-\%, a shrinkage in $\mathrm{x}-\mathrm{y}$ direction (not thickness) of $\geq 16 \%$, a sintering thickness of 350-800 $\mu \mathrm{m}$ and a pore size of approx. 40 $\mu \mathrm{m}$ are required. Based on these defined values, it was possible to deduce the properties of bulk density, tap density and specific surface area (BET) of the Fe26Cr1MoTi powder processed in the substrate tapes. As target ranges for flake shaped metal particles from attritor milling, a bulk density of 0.2-0.5 g / $\mathrm{cm}^{3}$, a tap density of 0.4-1 $\mathrm{g} / \mathrm{cm}^{3}$ and a BET of 0.6-0.8 $\mathrm{m}^{2} / \mathrm{g}$ were defined. Table 2 shows the values achieved as a function of the treatment time and the used starting fraction. The powders milled in the high energy mill were found to provide a similar result to the attritor powders. However, the HEM method is more attractive for later production due to time savings and larger processing amounts. 
The evaluation of the milled Fe26Cr1MoTi powders revealed that the target powder size range was achieved by powder modifications A1 and A3. The HEM milled powders do not yet reach the defined values, especially with respect to the specific surface.

Based on selected samples, the carbon and oxygen content was determined (Table 3). It can be seen that the oxygen content in the attritor increases with increasing milling time. The carbon content is higher after milling in the HEM and, in contrast to attritor milling, also increases with increasing milling time in the HEM. $\mathrm{C}$ and $\mathrm{O}$ content is subject of further optimization of the milling process.

Table 2: Remark of produced Fe26Cr1MoTi powders (green: in target, red: out of target)

\begin{tabular}{|c|c|c|c|c|c|c|}
\hline \multirow{2}{*}{ 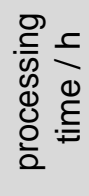 } & \multirow[t]{2}{*}{ 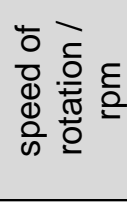 } & \multirow[t]{2}{*}{ 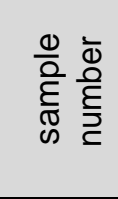 } & \multirow[t]{2}{*}{ 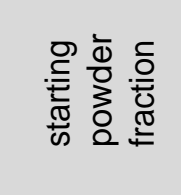 } & \multicolumn{2}{|c|}{ 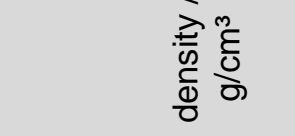 } & \multirow[t]{2}{*}{ 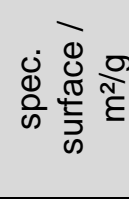 } \\
\hline & & & & bulk- & tap- & \\
\hline \multicolumn{7}{|c|}{ attritor } \\
\hline 2 & 800 & A1 & $<38 \mu \mathrm{m}$ & 0,281 & 0,561 & 0,59 \\
\hline 3 & 800 & A2 & $<38 \mu \mathrm{m}$ & 0,283 & 0,59 & 0,96 \\
\hline 2 & 800 & A3 & $38-125 \mu \mathrm{m}$ & 0,39 & 0,77 & 0,76 \\
\hline 3 & 800 & A4 & $38-125 \mu \mathrm{m}$ & 0,357 & 0,713 & 1,02 \\
\hline 4 & 800 & A5 & $38-125 \mu \mathrm{m}$ & 0,309 & 0,616 & 1,03 \\
\hline 4 & 800 & A6 & $<38 \mu \mathrm{m}$ & 0,385 & 0,782 & 1,11 \\
\hline 1 & 800 & A7 & $38-125 \mu \mathrm{m}$ & 0,504 & 0,867 & 0,37 \\
\hline \multicolumn{7}{|c|}{ high energy milling } \\
\hline 2 & 1200 & HEM1 & $38-125 \mu \mathrm{m}$ & 0,591 & 0,881 & 0,23 \\
\hline 3 & 1200 & HEM2 & $38-125 \mu \mathrm{m}$ & 0,493 & 0,751 & 0,31 \\
\hline 4 & 1200 & HEM3 & $38-125 \mu \mathrm{m}$ & 0,506 & 0,823 & 0,45 \\
\hline 2 & 1200 & HEM4 & $<38 \mu \mathrm{m}$ & 0,665 & 1,054 & 0,31 \\
\hline 3 & 1200 & HEM5 & $<38 \mu \mathrm{m}$ & 0,661 & 1,126 & 0,38 \\
\hline
\end{tabular}

Table 3: $\mathrm{C}$ and $\mathrm{O}$ contents of produced Fe26Cr1MoTi powders

\begin{tabular}{|c|c|c|c|c|c|c|}
\hline 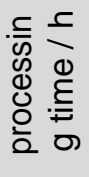 & 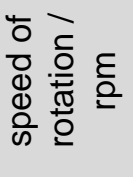 & 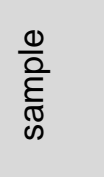 & 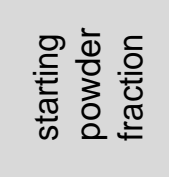 & 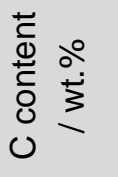 & Õ $\stackrel{\circ}{\circ}$ & 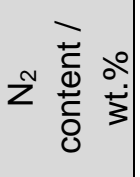 \\
\hline \multicolumn{7}{|c|}{ attritor } \\
\hline 2 & 800 & A1 & $<38 \mu \mathrm{m}$ & 0,109 & 0,474 & 0,14 \\
\hline 4 & 800 & A5 & $38-125 \mu \mathrm{m}$ & 0,196 & 0,931 & 0,12 \\
\hline 1 & 800 & A7 & $38-125 \mu \mathrm{m}$ & 0,113 & 0,34 & 0,14 \\
\hline \multicolumn{7}{|c|}{ high energy milling } \\
\hline 2 & 1200 & HEM1 & $38-125 \mu \mathrm{m}$ & 0,408 & 0,458 & 0,14 \\
\hline 4 & 1200 & HEM3 & $38-125 \mu \mathrm{m}$ & 1,11 & 1,08 & 0,15 \\
\hline
\end{tabular}

The starting fractions (Figure 1) show, as expected, a spherical appearance. Flake shaped particles can be produced by attritor but also HEM milling (Figure 2).

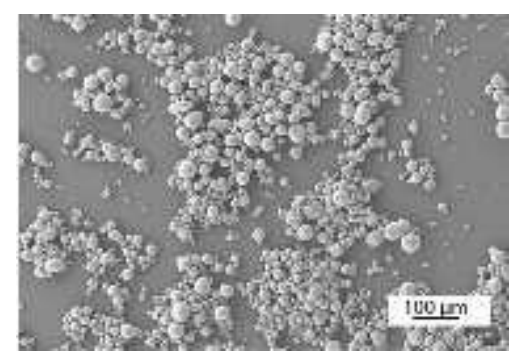

$\mu \mathrm{m}$ fraction (left) and $+38-125 \mu \mathrm{m}$ fraction (right)

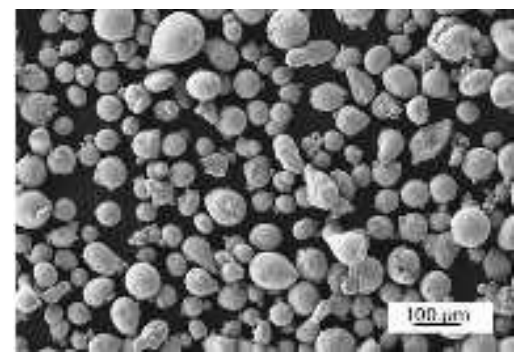

Figure 1: Starting powder -38 

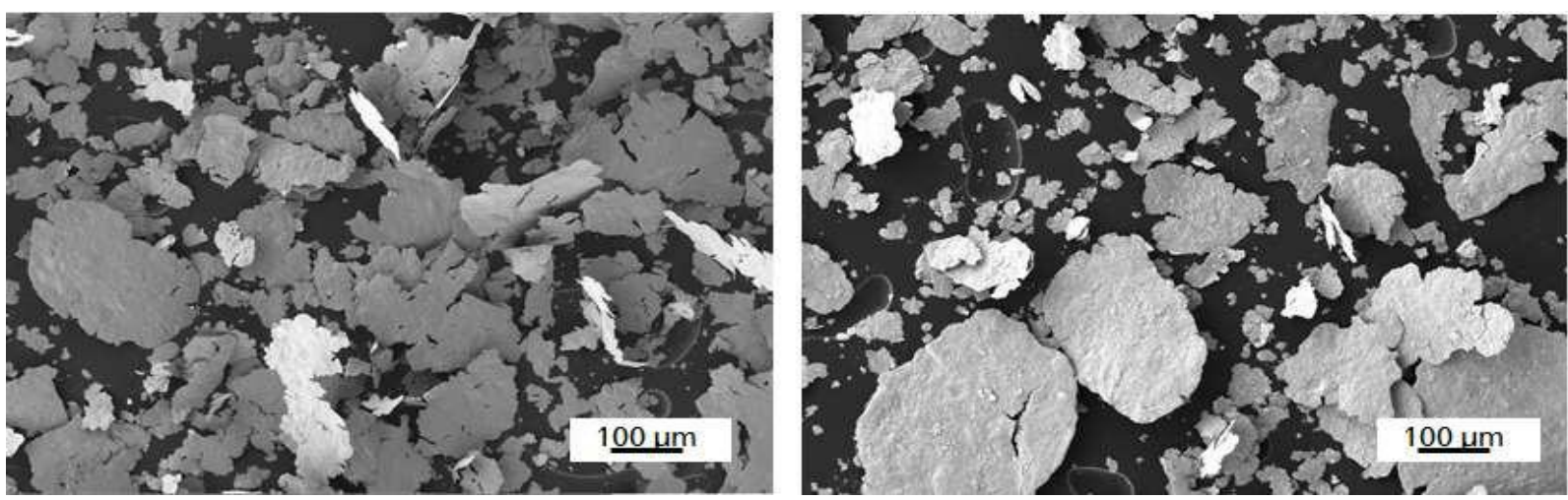

Figure 2: Attritor powder A1 (left) und HEM1 (right) after 2h milling time

The difference of the two powders from the different milling aggregates becomes visible on the basis of the flake shape and size. After 2 hours attritor treatment very flat and partly already broken flakes are present, the HEM treatment with the same milling time leads to round shaped flakes, but also many very small particles that have broken out of the initial cold-strengthened flakes.
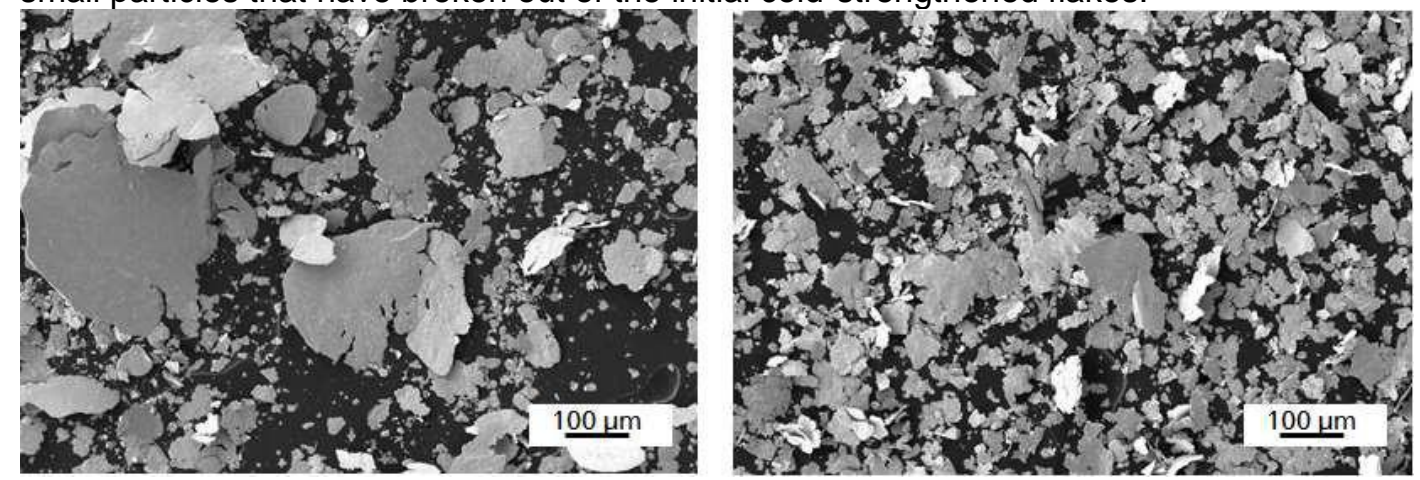

Figure 3: Attritor powder $\mathrm{A} 5$ and $\mathrm{A} 7$ after $1 \mathrm{~h}$ (left) and $4 \mathrm{~h}$ (right) milling time

The effect of increasing grinding time in the attritor can be clearly seen in the resulting particle size. The effect during grinding is, that the platelets that are formed first harden, crack and crush into fine, irregular metal particles as a result of work hardening processes (Figure 3).

The usability of the tape casted metal substrate was analyzed by characterization of the shrinkage behavior during sintering (Table 1). It shows that metal tapes based on attritor but also of HEM milled powders can meet the requirements of MSC substrates.

Table 4: Characterization of sintered substrates made of milled Fe26Cr1MoTi powder

\begin{tabular}{|c|c|c|c|c|}
\hline & 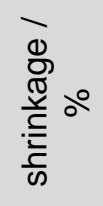 & $\frac{\circ}{\frac{0}{\infty}} \frac{\substack{\frac{1}{2} \\
\frac{0}{0}}}{\frac{0}{0}}$ & 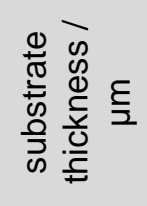 & powder properties \\
\hline $\mathrm{SP}+\mathrm{PF}$ & 6,6 & 37,6 & 620 & starting powder (SP) with pore former (PF) \\
\hline A1 & 31,4 & 41,9 & 860 & \multirow{2}{*}{$\begin{array}{l}\text { attritor: } 800 \mathrm{rpm}, 2 \mathrm{~h},-125+38 \mu \mathrm{m} \\
\rho_{\text {bulk }}=0,28 \mathrm{~g} / \mathrm{cm}^{3} ; \rho_{\text {tap }}=0,56 \mathrm{~g} / \mathrm{cm}^{3} ; \\
\mathrm{BET}=0,59 \mathrm{~m}^{2} / \mathrm{g}\end{array}$} \\
\hline A1 covered & 22,7 & 43,3 & 610 & \\
\hline A3 & 28,4 & 32,1 & 640 & \multirow{2}{*}{$\begin{array}{l}\text { attritor: } 800 \mathrm{rpm}, 2 \mathrm{~h},-38 \mu \mathrm{m} \\
\rho_{\text {bulk }}=0,39 \mathrm{~g} / \mathrm{cm}^{3} ; \rho_{\text {tap }}=0,77 \mathrm{~g} / \mathrm{cm}^{3} ; \\
\mathrm{BET}=0,76 \mathrm{~m}^{2} / \mathrm{g}\end{array}$} \\
\hline A3 covered & 23,3 & 33,0 & 580 & \\
\hline
\end{tabular}

Table 4 summarizes the properties of sintered metal substrates.

Additions of pore former to the starting powder leads to high open porosities, but the corresponding shrinkage stays far too low. That is why the use of milled powder is essential. By using a cover plate (porous $\mathrm{Al}_{2} \mathrm{O}_{3}$ plate, $100 \times 100 \times 1 \mathrm{~mm}$ ) during sintering the samples without pore formers, the thickness shrinkage changes. Other important results are the final pore size distribution and the pore shape, which can be visualized by microscopic photographs after sintering. 

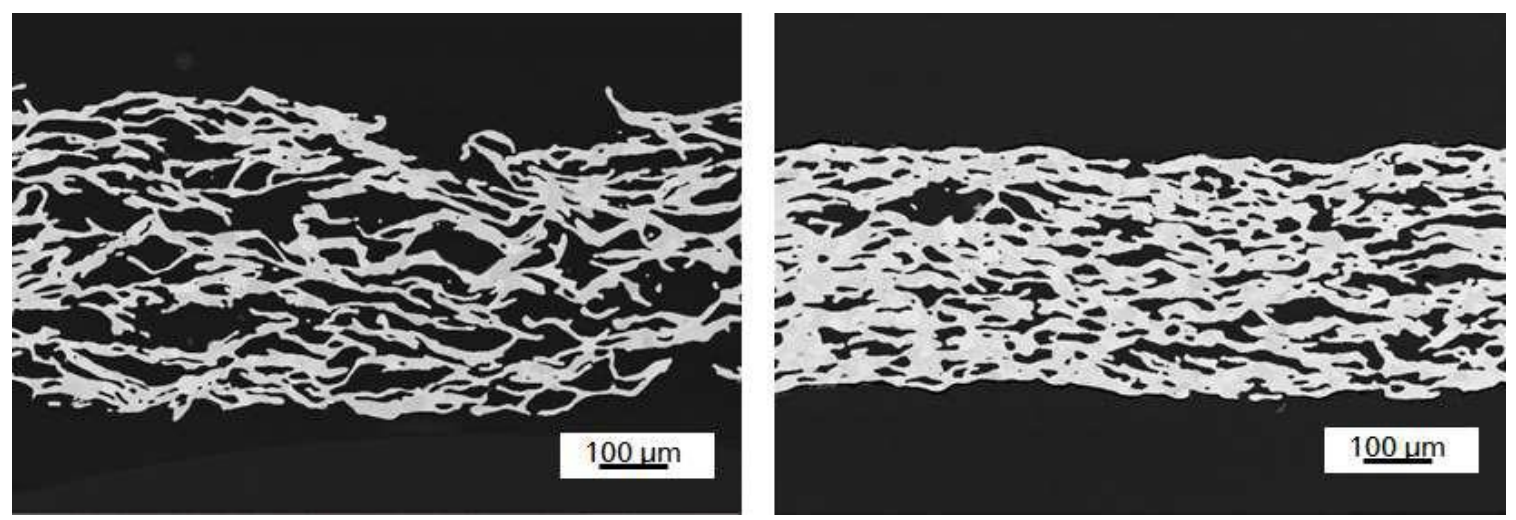

Figure 4: Attritor powder A1, -38 $\mu \mathrm{m}$ (left) and A3, -125+38 $\mu \mathrm{m}$ (right) after $2 \mathrm{~h}$ milling time

On the one hand, it can be noted that the choice of the starting fraction under the same milling conditions has a great influence on the porosity. Due to the different particle size, the milling results show significant differences in the sintering, the flatness but especially in the pore shape. A substrate having rounder pores, a planar surface and a stable particle composite, such as the sintered A3 tape, is preferred. Longterm aging of the substrates in a fuel gas atmosphere for the determination of the oxidation stability under reducing conditions are planned. Although the powder properties after milling (bulk density, tap density and BET) and also the target parameters of the substrate properties after sintering seemed initially similar, the FESEM images show qualitative differences, which have to be considered for the powder and substrate selection.
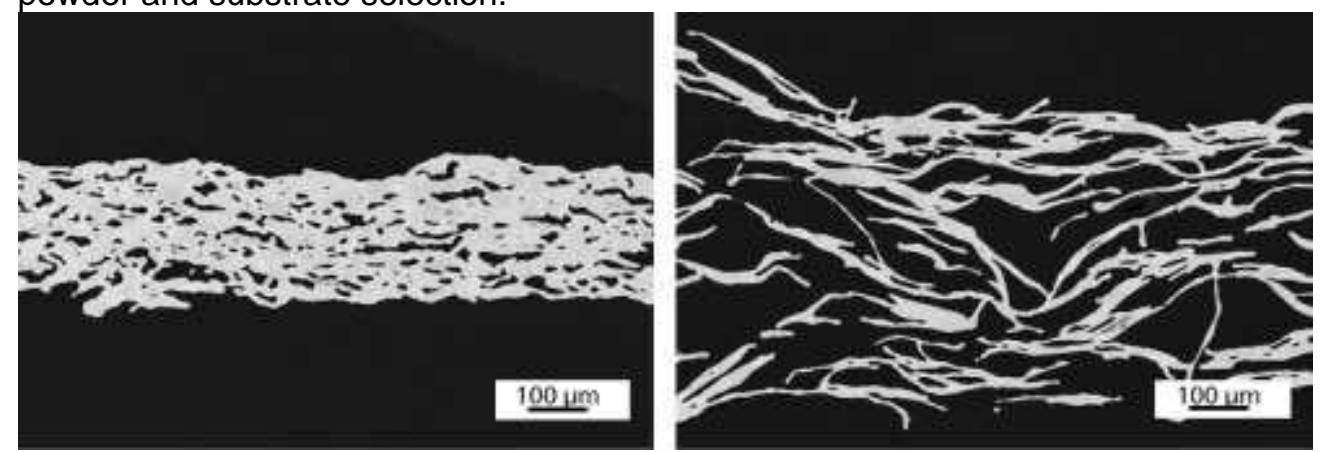

Figure 5: Substrates of A5 (4h) and A7 (1h) powders

As already assumed in Figure 3, Figure 5 shows that the milling time has a significant influence on the subsequent sintering behavior. While very flake shaped particles lead to a rough tape with inhomogeneous porosity after $1 \mathrm{~h}$ milling time, the finer particles formed after $4 \mathrm{~h}$ lead to flat and very dense films with a significantly lower open porosity and round pores.

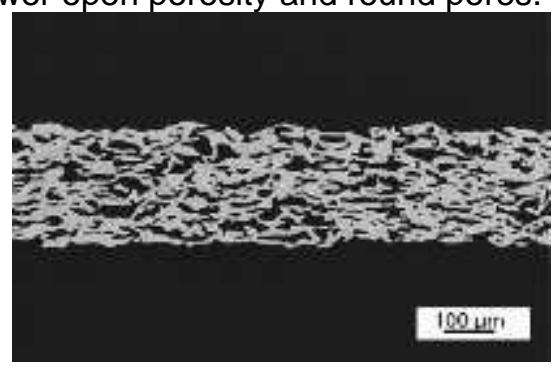

Figure 6: Substrate of HEM4 powder

Although the powder properties of the HEM powders were not reached (Table 2), it was still possible to produce tapes (Figure 6) that matched the favored specification - compared to substrate A3 after attritor milling. The approach of HEM milling is pursued on the basis of this.

\section{Summary}

The combination of powder modification by milling technologies followed by further processing in tape casting process into metal layers is an innovative approach for the future production of cost-effective and reproducible metal substrates for metal-supported cells (MSCs). By using metal powders in combination with high energy milling process and adjusting the shrinkage of the metal tape based on mixtures of powders with different shape and size, the shrinkage and porosity of the final tape can be 
controlled. In a next step the co-firing with ceramic electrolyte layer will be evaluated. The milling and tape casting process also leads to low process costs, low waste of materials and is suitable for large scale production.

\section{Acknowledgements}

The European Regional Development Fund (ERDF) through the Sächsische Aufbaubank (SAB) kindly supports this research project (No. 100269554).

\section{References}

[1] Ferdi Schüth, "Energieversorgung der Zukunft - der Beitrag der Chemie -", 2007.

[2] U. Flach, U. Burchardt, H.-J. Fell, A. E. Fischer, A. Marquardt, "Technikfolgenabschätzung:

„Brennstoffzellen-Technologie", Drucksache 14/5054", 2001.

[3] S. Kavurucu Schubert, Effects of hydrogen sulfide in fuel gas on SOFC stack performance with nickel containing anodes 2012.

[4] Y.Shiratori, T.ljichi, T.Oshima, K. Sasaki, International Journal of Hydrogen Energy 2010, 35, 7905.

[5] M. P. Heddrich, Thermodynamische Analyse von SOFC-Systemkonzepten und experimentelle Validierung 2012.

[6] Fuel Cells Bulletin 2012, 7.

[7] V. Lawlor, S. Griesser, G. Buchinger, A. G. Olabi, S. Cordiner, D. Meissner, Journal of Power Sources 2009, 193, 387.

[8] Fuel Cells Bulletin 2010, 2010, 1.

[9] Fuel Cells Bulletin 2011, 2011, 10.

[10] S. P. S. Badwal, K. Foger, Ceramics International 1996, 22, 257.

[11] T. Franco, Entwicklung und Charakterisierung von anodenseitigen Diffusionsbarriereschichten für metallgetragene oxidkeramische Festelektrolyt-Brennstoffzellen 2009.

[12] S.Visco, C. P. Jacobson, L. C. De Jonghe, in SECA Core Technology Program Review, 2003.

[13] M. C. Tucker, T. Z. Sholklapper, G. Y. Lau, L. C. DeJonghe, S. J. Visco, in Solid Oxide Fuel Cells 11 (SOFC-XI), Vol. Vienna (Eds: S. C. Singhal, H. Yokokawa), The Electrochemical Society, 2009.

[14] T. Klemensø, J. Nielsen, P. Blennow, Å. H. Persson, T. Stegk, B. H. Christensen, S. Sønderby, Journal of Power Sources 2011, 196, 9459.

[15] M. Haydn, K. Ortner, T. Franco, S. Uhlenbruck, N. H. Menzler, D. Stöver, G. Bräuer, A.

Venskutonis, L. S. Sigl, H.-P. Buchkremer, R. Vaßen, Journal of Power Sources 256 (2014) 52-60.

[16] E. Ivers-Tiffee, W. Wersing, M. SchießI, H. Greiner, Ber. Bunsenges. Phys. Chem. 1990, 94, 978.

[17] W. J. Quadakkers, V. Shemet, L. Singheiser, DE 10025108 A1, 2001.

[18] AT 004810 U1, 2001.

[19] T. Uehara, A. Toji, T. Ohno, EP 1298228 A2, 2003. Effiziente Energiewandler für dezentrale Stromversorgung auf Basis von Metall-Keramik-Verbunden 33

[20] S. Ide, S. Ishikawa, K. Takao, O. Furukimi, K. Fukuda, A. Miyazaki, EP 1536031 A1, 2005.

[21] H. Hattendorf, B. Kuhn, T. Eckardt, T. Beck, W. J. Quadakkers, W. Theisen, N. Nabiran, DE 10 2012004488 A1, 2012.

[22] M. Schuisky, L. Gutzon, N. Christiansen, L. Mikkelsen, EP 1882756 A1, 2008.

[23] G. Schiller, R. Henne, M. Lang, ECS Proceedings 1997, 97, 635.

[24] M. Lang, P. Szabo, Z. Ilhan, S. Cinque, T. Franco, G. Schiller, Journal of Fuel Cell Science and Technology 2007, 4, 384.

[25] I. Gibson, D.W. Rosen, B. Stucker, 2015, Additive Manufacturing Technologies: 3D Printing, Rapid Prototyping, and Direct Digital Manufacturing, Springer, pp. 1-498.I. Antepara, I. Villarreal, L. M. Rodriguez-Martinez, N. Lecanda, U. Castro, A. Laresgoiti, Journal of Power Sources 2005, 151, 103. DOI: 10.1016/j.jpowsour.2005.02.084.

[26] M. Brandner, Herstellung einer Metall/Keramik-Verbundstruktur für Hochtemperaturbrennstoffzellen in mobilen Anwendungen 2006.

[27] T. Franco, R. Ruckdäschel, M. Lang, G. Schiller, P. Szabo, in Lucerne Fuel Cell Forum 2006 (Ed: U. Bossel), Luzern, Schweiz, 2006. 